\title{
$\mathrm{V}$ 型溝内面の相互反射と色ずれ
}

\author{
正会員 福井和 久 海*
}

\section{Interflection and Color Shift on Surfaces with Multiple V-shaped Grooves}

\author{
Wakumi Fukui (Member)
}

(Himeji Institute of Technology)

\begin{abstract}
Specimens used in this experiment are multiple V-shaped grooves with included angels of $60^{\circ}, 30^{\circ}$, $15^{\circ}$ and flat surfaces made of aluminium. Their surfaces were coated with three kinds of colors, blue, reddish purple and yellow after sprayed with primer.

Their spectral reflectance curves were taken by G.E. Recording Spectrophotometer, and their chromaticities and luminous reflectances calculated to be compared with the analytical results.

Consequently, general tendency of color shift, monochroic- and dichroic color shift due to the increase of interflection could be traced.
\end{abstract}

\section{1. 緒言}

最近，照明括よび熱の分野に括いて相互反射が取り上 げられているが，これは照明では室内に拈ける相互反射 とそれに伴ら色ずれの問題となって，一部に検討1)され ている.

他方, California 大学工学部の O'Brien 教授の研究 室では, 平板をV型に重奴てその相互反射の計算と実験 を行なっていたので，この実験に関連して相互反射と色 ずれの関係を検討すべく，同教授の指示のもとに試料を 製作して測定と計算を試みた。

\section{2. 試料および測定}

まず頂角 $\theta$ が $60^{\circ}, 30^{\circ}, 15^{\circ}$ であるような幾つかの V 型 溝を表面にもつ直方体と, 基準となる平面板 $\left(\theta=180^{\circ}\right)$ をアルミニウムを用いて製作し，その表面にはプライマ 一を塗布した後に青色, 黄色, 赤紫色の塗料を吹きつけ て陚料とした.これらの塗料はいずれも不透明, 拡散性 のもので, 種類怙よび色は次のようである.

青色塗料……...Pittsburgh Paints, 5-p-19.

黄色塗料..........Pittsburgh Paints, Yellow, 11-2.

赤紫色塗料…....Tempera, Magenta.

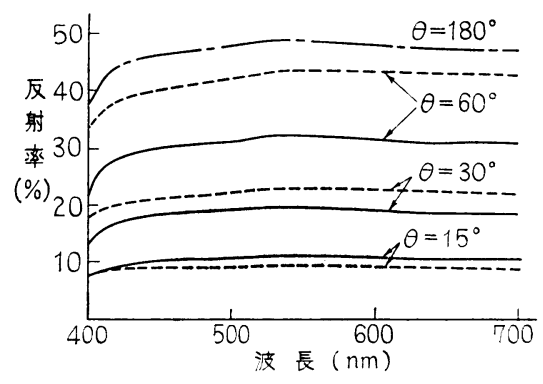

第 1 图 アルミニウムV型漊の分光反射率曲線

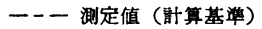

...... 测定值 - 斯算值

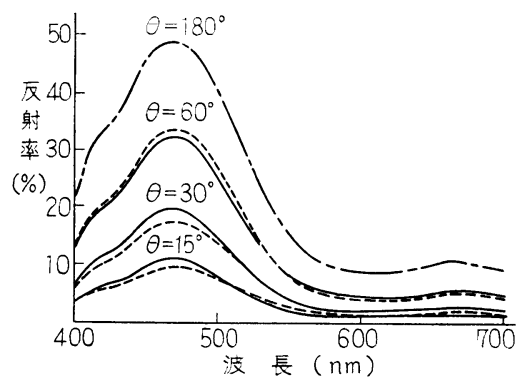

第 2 図青色V型清の分光反射夷曲線 - - - 測定值（計算基菹） …... 测定値 — 针算值 


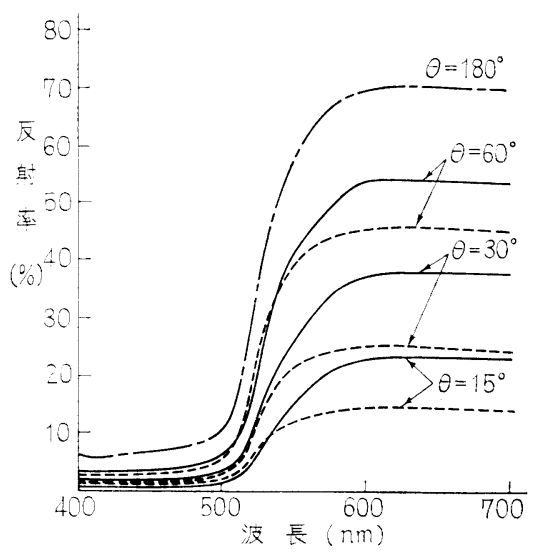

第 3 図黄色 $\mathrm{V}$ 型漸の分光反射率曲線 - - - 測定值（計算基準） …… 测定値 一 乾算值

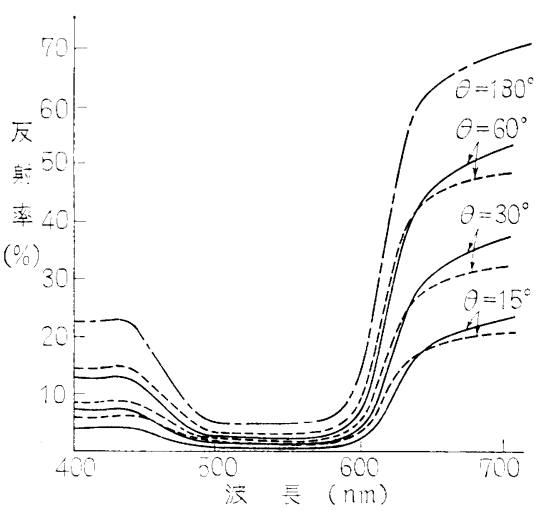

第 4 图 赤紫色 $\mathrm{V}$ 型瑇の分光反射率曲線 - - - 测定値（即算基游） …… 測定值 … 部算值

また，試料の大きさは $42.9 \times 42.9 \times 38.1 \mathrm{~mm}^{3}$ で，溝 の間隔は約 $4.8 \mathrm{~mm}$ である。

これらの試料の分光反射率を GE 製の自記分光光度計 によって測定して分光反射率曲線を得，乙れから計算に よって種々の結果を導き出した。

試料製作過程中拉よび製作後にとった分光反射率曲線 を第 1，2，3，4 図に示す.

\section{3. 相 互 反 射}

完全桩散性をもつ $n$ 個の平面からなる相互反射系に拉 いて, 面 $i$ の初期光束発散度を $L_{o} i$, 相互反射後の光束 発散度を $L_{i}$, 反射率を $\rho_{i}$ とすると, 次の関係式が成立 する2).

$$
L_{i}=L_{0 i}+o_{i} \sum_{\substack{j=1 \\(i \neq j)}}^{n} F(i, j) L_{j}
$$

ただし $, \quad i=1,2 \cdots \cdots \cdots n$

$$
F(i, j)=\frac{1}{\pi A_{i}} \int_{A_{j}} \int_{A_{i}} \frac{\cos \theta_{i} \cdot \cos \theta j}{r_{i j^{2}}} d A_{i} d A_{j}
$$

ここに, $A_{i}$ : 面 $i$ の面積, $F(i, j)$ : 面 $i, j$ 間の Shape Factor, $r_{i j}$ : 面 $i$ 扣よび面 $j$ 上の微少面積 $d A_{i}$ 执よび $d A_{j}$ 間の距離, $\theta_{i}, \theta_{j}$ : 面素 $d A_{i}$ 执よび $d A_{j}$ の法線と それらを結ぶ直線とのなす角度である。

測定に使用した分光光度計では，試料にほとんど垂直 に平行な単色光が入射していると考えられるから，次の ような仮定を扣いて，V型溝内面に拈ける相互反射の式 を簡単にして計算をすすめた。

(1) $\mathrm{V}$ 型溝の対称軸に平行な光が溝の表面に一様に入 射する.

(2) V型溝表面は全体にわたって完全拡散性である.

(3) V 型溝は無限辰，かつ対称である.

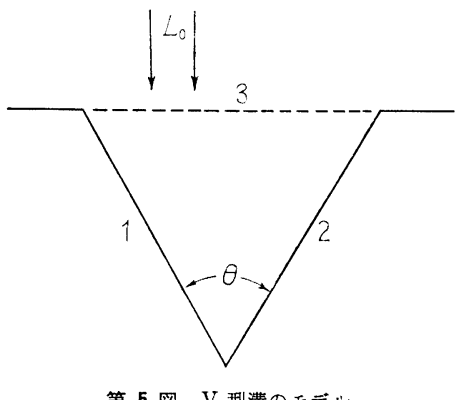

第 5 図 $V$ 型溝のモデル

第 5 図において，V 型溝の側面をそれぞれ面 1，2， 開口部を面 3 とし，面 $1 ， 2$ のなす角度を $\theta$ ，分光反射 率を $\rho_{\dot{\lambda}}$ ，羵位面積当たりの入射光束を $L_{0}$ とすると， 面 1，2 は対称であるから，これらの面の光束発散度は ともに等しくして

$$
\rho_{\lambda} \cdot L_{0} \cdot \sin \left(\frac{\theta}{2}\right)
$$

となる、これを初期光束発散度 L $0 s$ と拈くと，

$$
L_{01}=L_{02}=L_{0 s}=\rho_{\lambda} \cdot L_{0} \cdot \sin \left(\frac{\theta}{2}\right)
$$

面 1，2 の相互反射後の光束発散度を $L_{s}$ とすると，(1) 式から

$$
L_{1}=L_{2}=L_{s}=L_{0 s}+\rho_{\lambda} F(1,2) L_{s}
$$

実効反射率を $\rho_{\text {גeff }}$ とすると，

$$
\rho_{\text {ieff }}=\frac{(\text { Flux out })}{(\text { Flux in })}=\frac{F(3,1+2) \cdot L_{s} \cdot A_{3}}{L_{0} A_{3}}
$$

ただし， $A_{3}: \mathrm{V}$ 型溝の開口部 3 の面積.

(2)式を参照して

$F(1,2)$ : 面 1, 2 の間の Shape Factor. また $F(1,2)=1-\sin \left(\frac{\theta}{2}\right)^{3)}$

$F(3,1+2)$ : 面 3 と面 1,2 との間の Shape Factor 
この場合，面 3，1，2 は閉面を形成するから， $F(3,1+2)=F(3,1)+F(3,2)=1$

$$
\therefore \quad \rho_{\lambda \text { eff }}=\frac{o_{\lambda} \cdot \sin \left(\frac{\theta}{2}\right)}{1-o_{\lambda}\left[1-\sin \left(\frac{\theta}{2}\right)\right]} \text {. }
$$

ここで，分光反射率 $\rho_{\lambda}$ にかえて反射率 $\rho$ を用いる と，その実効反射率 $\rho_{\mathrm{eff}}$ は次のようになる。

$$
\rho_{\mathrm{eff}}=\frac{\rho \sin \left(\frac{\theta}{2}\right)}{1-\rho\left[1-\sin \left(\frac{\theta}{2}\right)\right]}
$$

ただし，

$$
\rho=\frac{\int_{\lambda 1}^{\lambda 2} \rho_{\lambda} P_{\lambda} \bar{y}_{\lambda} d \lambda}{\int_{\lambda 1}^{\lambda 2} P_{\lambda} \bar{y}_{\lambda} d \lambda}
$$

各色の平面 $\left(\theta=180^{\circ}\right)$ の試料の示す分光反射率曲線と 上記の式とから, $\theta=60^{\circ}, 30^{\circ}, 15^{\circ}$ の場合の計算を行な って結果を図示すると, 前掲の第 $1,2,3,4$ 目の実線 の部分となる.

次に (3), (4) 式から, 分光反射率 $\rho_{\lambda}$ と実効分光反射率 $\rho_{\text {גeff }}$ および反射率 $\rho$ と実効反射率 $\rho_{\text {eff }}$ との関係を $\theta=$
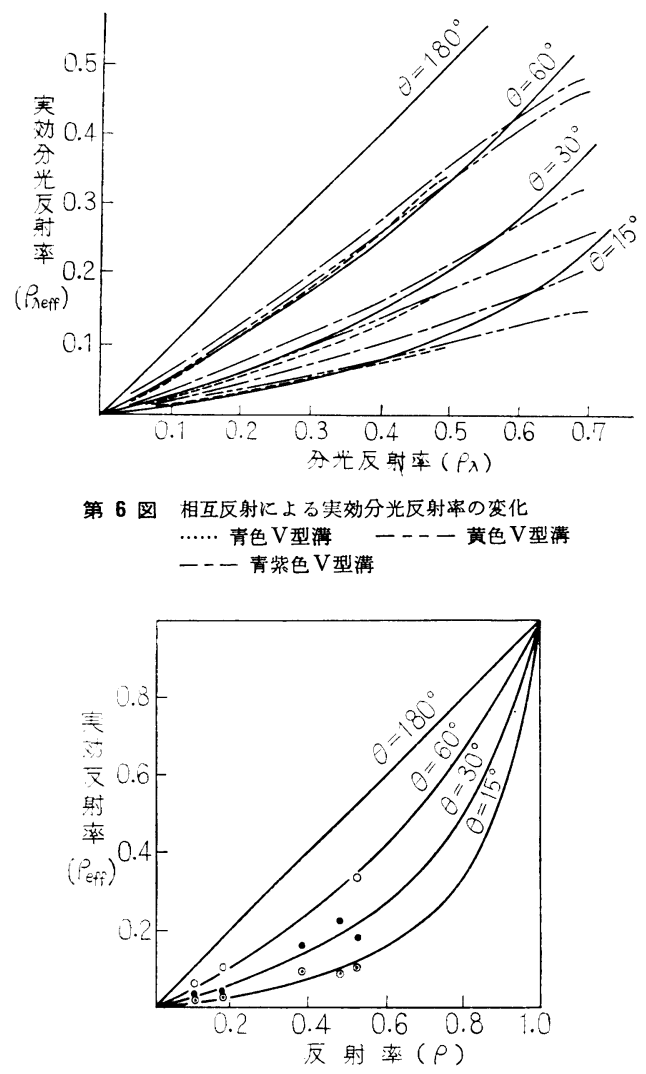

第 7 图相互反射に上る実奻反射率の变化 一計算值 $\bigcirc: \theta=60^{\circ}$ 测定値 ○: $\theta=30^{\circ}$ 測定值 (): $\theta=15^{\circ}$ 测定値 $180^{\circ}, 60^{\circ}, 30^{\circ}, 15^{\circ}$ の各場会について計算し, これらと 测定値とを比較すると，第 6 図，第 7 図となる.

$\theta=60^{\circ}$ のものでは測定值と理論值とがよく一致して いるが, $\theta=30^{\circ}, 15^{\circ}$ と角度が減少するにつれてずれが 大きくなっている. また一般に $\rho_{\lambda}, \rho$ の值が大きくなる と, $\rho_{\text {גeff }}, \rho_{\text {eff }}$ が相対的に減少しているが，これも $\theta$ が 小さくなるほどずれが大きくなっている.

\section{4.色 ず れ}

$\mathrm{CIE}$ の測色值 $x, y, Y$ は次の式によって計算される.

$$
\begin{aligned}
& \left(\begin{array}{l}
X \\
Y \\
Z
\end{array}\right)=K \int_{\lambda 1}^{\lambda 2} P_{\lambda} o_{\lambda}\left(\begin{array}{l}
\bar{x}_{\lambda} \\
\bar{y}_{\lambda} \\
\bar{z}_{\lambda}
\end{array}\right) d \lambda . \\
& \left(\begin{array}{l}
x \\
y \\
z
\end{array}\right)=\frac{1}{\mathrm{X}+Y+Z}\left(\begin{array}{l}
X \\
Y \\
Z
\end{array}\right) \\
& K=\left(\int_{\lambda 1}^{\lambda 2} P_{\lambda} \bar{y}_{\lambda} d \lambda\right)^{-1}
\end{aligned}
$$

ここに, $\bar{x}_{\lambda}, \bar{y}_{\lambda}, \bar{z}_{\lambda}$ : スペクトル三刺激值, $\rho_{\lambda}$ : 分光反 射率, $P_{\lambda}:$ 分光エネルギー分布.

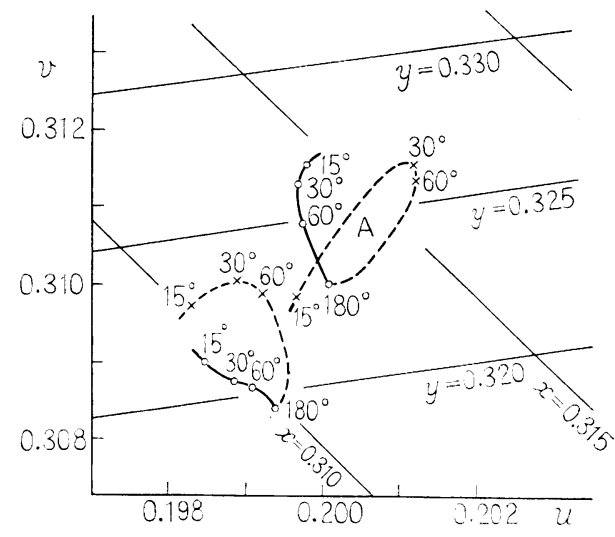

第 8 図 アルミニウム (A) およびブライマー 淘布 $(\mathrm{P}) \mathrm{V}$ 型淺の色すれれ

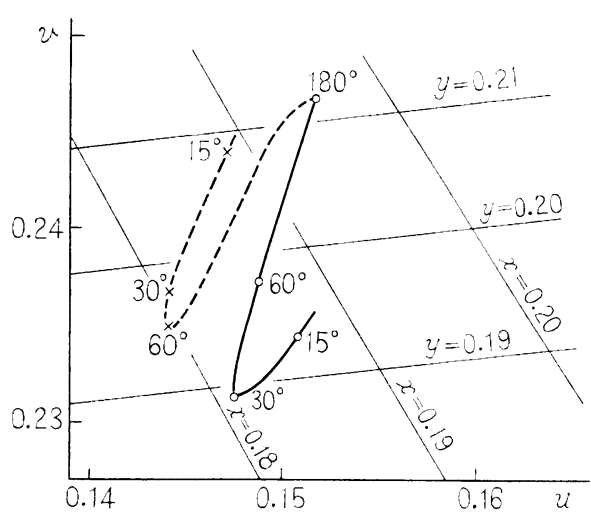

第 9 図青色 V型漊の色すれ 部算值 $\quad \cdots . .$. 测定値 


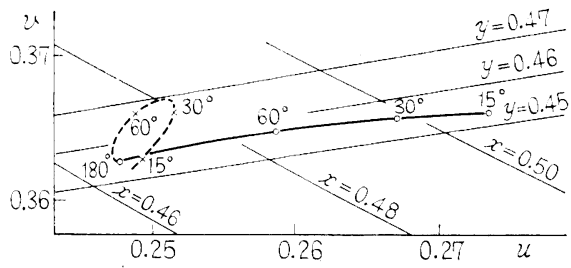

第 10 図黄色V型清の色ずれ
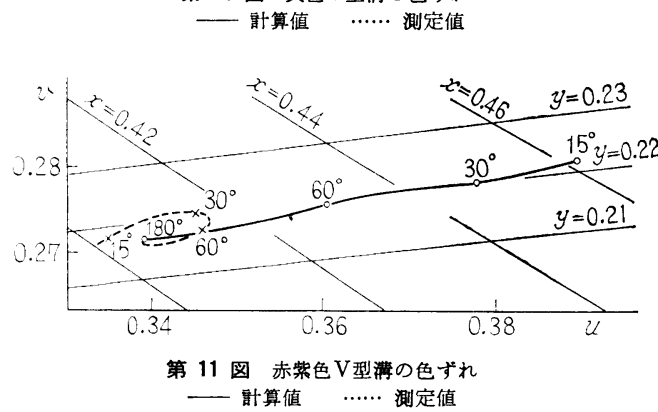

以上の式と前掲の分光反射率曲線とから計算して得ら れた測色值を $u v$ 座標上に記入すると，第 8, 9, 10,11 図 となる.ただしこの計算は $\mathrm{C}$ 光源を基淮として行なっ た.

理論値から測定值がずれる様子を色度図上に表示する と，第 12，13，14，15 図のようになる．ここではC 光源 の色度点を中心として, 各色度点をスペクトル色軌跡上 扣よび純紫軌跡上，あるいはこれらに平行な線上に投影 してずれの方向と大きさを示した.

これをまとめると次のようになる。

（1）理論値からのずれの方向黄色の試料では，ず れは時計の回転と反対の方向であるが，赤紫色拉よび青 色の試料では時計の回転方向になっている。これら二つ の相反する方向をもつずれは，スペクトル色軌跡上 540

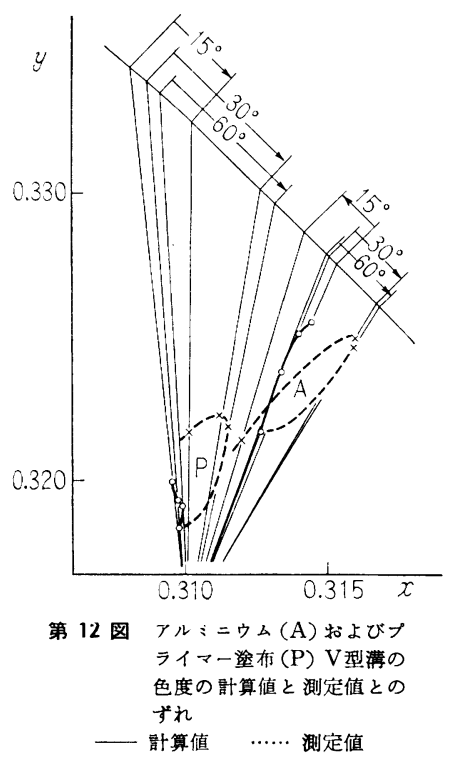

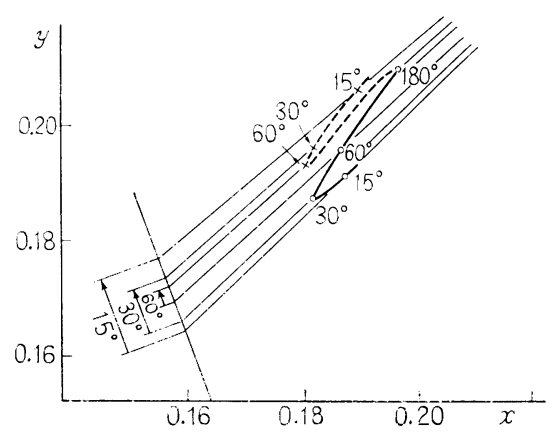

第 13 图 青色 V型溝の色度の計算値と湘定値 とのずれ 一計算值 $\quad \cdots . .$. 测定值

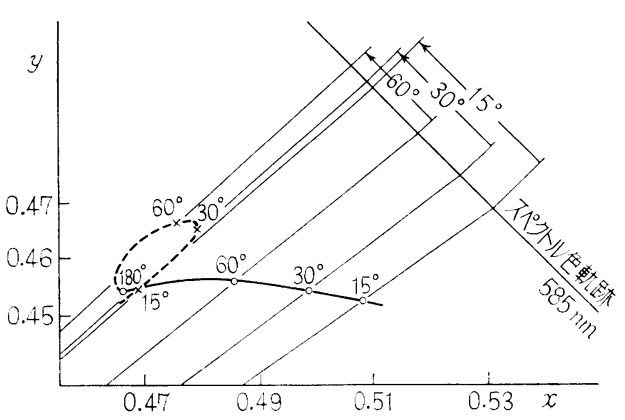

第 14 图 黄色V 型溝の色度の計算値と測定値 とのずれ —計算値 $\quad \cdots . .$. 測定值

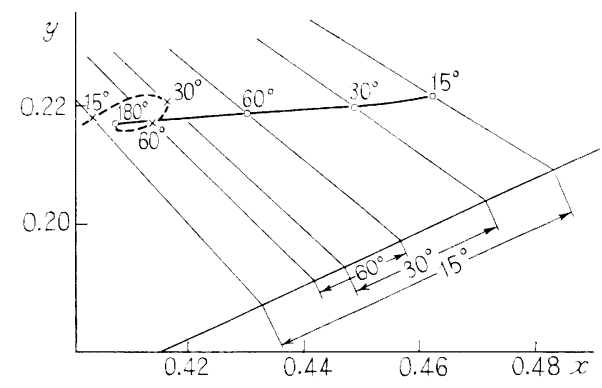

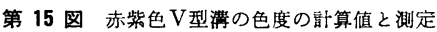
㯰とのずれ

一即算値 $\quad$....... 测定值

〜 $570 \mathrm{~nm}$ 付近で合する. この結果, 第 12 図のアルミニ ウム試料にみられるように，ずれの方向が一様でなくな る.

（2）理論值からのずれの大きさ黄色，赤紫色执よ び青色の試料では，ずれはいずれも $\theta=15^{\circ}$ のものが最 大, $\theta=60^{\circ}$ のものが最少であるが，前述の範囲では逆 に $\theta=15^{\circ}$ のものが最小, $\theta=60^{\circ}$ のものが最大であっ たり，三者が類似した大きさを示すようになっている.

以上の変化は, 相反する方向と異なる大きさをるった 二つのベクトル和に類似している.

さて，目は色の弁別にすこぶる敏感であるといわれる 
から，測定もさることながら，これらの試料を目で観察 したときの色ずれの感じ方も興味ある問題である.

概観したところでは，いずれも溝が深くなるにつれて 明度が低下して色が暗くなり，これが色ずれの感じを左 右するようであった.このうち, 黄色の試料では, $\theta=$ $60^{\circ}$ になるとわずかに緑色がかった黄色の反射光がちら つくようになり, $\theta=30^{\circ}, 15^{\circ}$ となるのにつれて, この ららつきの消えていくのが観察された。

\section{5. 考察}

（1）試料表面の完全拡散性からのずれ 加工直後の アルミニウム試料にはにぶい金属光沢があり，その分光 特性（第 1 図）でも理論值よりかなり増加したものがあ るのをみると，この試料では正反射性が残り，完全抎散 性からはずれていたことが考えられる。

この素材の上に不透明，抎散性の塗料を吹きつけると 当然拡散性が增す。そして測定值も理論值に近ついてき てはいるが，概して反射率の高いところでそれより減少 したものとなっている（第 $2 ， 3 ４$ 図).こうしたずれ は試料の表面が完全扗散性でなかったことにあるといえ る.

（2）試料の取付け位置 $\mathrm{GE}$ 分光光度計では標準白 色板と平面の陚料とを同じ相対位㯰に括いて测定するこ とになっていて，この位置からずれると測定值が変わる ともいわれる。

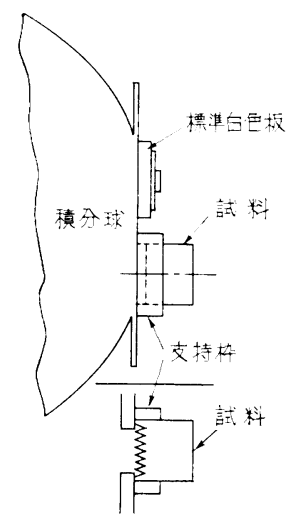

第 16 图試料の取付け位略

大きくなってくる.

(3) 試料の形 $\quad \mathrm{V}$ 型溝をつくる際には底部の成形が 困難で変形をさけ得ず，その上，塗料を吹きつけるとそ れが底にたまってU字形となる．また三角形の頂点のと ころでも同様な変形のあることが考えられる．こうした 変形は頂角が小さくなるほど著しくなり, 誤差の原因と なる。
さらに，溝は有限長であったから測定時にその端の部 分からもたらされる影響も無視できないものであったろ 5 .

こうしたさまざまな原因のために，測定結果は理論值 からずれ，ここに示したような分光反射率曲線，垁効反 射率および色ずれを示すものになった。

（4）色ずれ 相互反射に基づく色ずれの㴍子をみる と, 大体その主波長方向にずれるといってよいが，詳細 に検討すると Monochroic Color Shift と Dichroic Color Shift に分類されるようである.

i ) Monochroic Color Shift 分光反射率曲線が 一つの最大值を有するもの，あるいはこれに類似するよ らな色では相互反射が増すと，一般にその色は主波龙方 向にずれる，この実験では，赤紫色試料以外のものがす ベてこれに属する。

ii ) Dichroic Color Shift4) 分光反射淬曲線が波 長の長い側と短い側にそれぞれ極大值をもつもの，ある いはこれに類似する色の場合，相互反射が增すと色は光 源の色度点と大体主波辰 $600 \sim 650 \mathrm{~nm}$ を結ぶ線に平行 にずれる.すなわち，その色は主波病の示す色よりも赤 がかってくる.この実験では赤紫色の試料がこの傾向を 示している.この現象は黒沢博士の報告5)にもみられる がこれは二つの極大值をもつXのスペクトル刺激值曲 線とこの種の色の分光特性とが似ていることに関俰があ るように思われる。

\section{6. 結言}

この実験は V 型溝および円す(孔(6)7)について試みた ものであるが，試料の製作，分光光度計による测定およ び色度計算などは O'Brien 教授のもとで行なった。こ の間，懇切に指導してくださった同教授扣よび，実験中 さまざまの点で援助してくださった大学院学生諸君と職 員のかたがたに深く感謝いたします.

\section{参 考 文 献}

（1）納谷・山中：昭 36 電気関西支部連合大会 (222)

（2）佐土根・森田・猪野原：照学誌 49 （昭 40） 4

(3) J. Psarontharis: AIAA 1 (1963) 1880

(4) W.D. Wright: The measurement of Color. 235

(5) 黒沢 : 東芝レビュー 17 (1962) 927

（6）福井：昭 40 電気四学会連合大会（1282）

（7）福井：姫路工大研究報告 17 (1964)

（受付 1965 年 5 月 14 日） 